\title{
Student motivation of the Surgeon Dentist Major of the Veracruz-Boca del Río Area to Study a Postgraduate Program: A Comparative Study
}

\section{Motivación de estudiantes de la carrera de Cirujano Dentista de la zona conurbada Veracruz-Boca del Río para estudiar un posgrado: un estudio comparativo}

\author{
MORA-SÁNCHEZ, Aura Leonora†*, ROESCH-RAMOS, Laura, MORENO-MARIN, Flora and \\ ZAPIÉN-USCANGA, Antonio de Jesús
}

\author{
Universidad Veracruzana \\ ID $1^{\text {st }}$ Author: Aura Leonora, Mora-Sánchez \\ ID $1^{\text {st }}$ Coauthor: Laura, Roesch-Ramos / ORC ID: 0000-0003-0188-797X \\ ID $2^{\text {nd }}$ Coauthor: Flora, Moreno-Marin \\ ID $3^{\text {rd }}$ Coauthor: Antonio De Jesús, Zapién-Uscanga
}

DOI: $10.35429 / J S R .2019 .15 .5 .35 .46$

Received March 20, 2019; Accepted June 30, 2019

\begin{abstract}
Objectives: The objective that we intend to reach is to diagnose the motivation that our students of the last semesters of the Dental Surgeon Major of Veracruz-Boca del Río have to continue with postgraduate or specialty studies. Find out causes and factors that arouse this interest of both students of public institutions such as UV and private institutions such as CME and UVM. Methodology: Elaborate questionnaires that address the sociodemographic factors of each one; interviews with a small group of students to learn first-hand what their opinion is about postgraduate studies inside or outside the university, Likert scales to know the attitude of the students regarding the importance of doing postgraduate studies. Contribution: Despite comparing two private universities with a public one, there is no significant difference in terms of motivation to study a postgraduate program. However, it is interesting to know what the study shows the concern of the economic factor, the disinformation they have of the specialties, the little information provided from their respective institutions as well as not giving the necessary importance to be a specialist in a specific area to provide better patient care.
\end{abstract}

Motivation, Postgraduate, Students

\begin{abstract}
Resumen
Objetivos: El objetivo que pretendemos alcanzar es diagnosticar la motivación que nuestros estudiantes de los últimos grados de la carrera de Cirujano Dentista de Veracruz-Boca del Río que tienen para continuar con estudios de posgrado o especialidad. Averiguar causas y factores que despiertan este interés tanto del alumnado de instituciones públicas como la UV e instituciones privadas como el CME y la UVM. Metodología: Elaborar cuestionarios que aborden los factores sociodemográficos de cada; entrevistas a un grupo pequeño de alumnos para conocer de primera mano cuál es su opinión sobre los estudios de posgrado dentro o fuera de la universidad, alicar escalas Likert para conocer la actitud de los estudiantes frente a la importancia de realizar estudios de posgrado. Contribución: A pesar de comparar dos universidades privadas con una pública, no hay diferencia mucha diferencia significativa en lo que respecta a la motivación de estudiar un posgrado, pero es interesante saber lo que arroja el estudio como: la preocupación del factor económico que implica, de la desinformación que tienen de las especialidades, de la poca información brindada de parte de sus respectivas institituciones así como no darle la importancia necesaria a ser especialista en un área específica para brindar mejor atención a pacientes
\end{abstract}

Motivación, Posgrado, Estudiantes

Citation: MORA-SÁNCHEZ, Aura Leonora, ROESCH-RAMOS, Laura, MORENO-MARIN, Flora and ZAPIÉNUSCANGA, Antonio de Jesús. Student motivation of the Surgeon Dentist Major of the Veracruz-Boca del Río Area to Study a Postgraduate Program: A Comparative Study. Journal of Social Researches. 2019, 5-15: 35-46

\footnotetext{
*Correspondence to Author (email: aumora@uv.mx)

$\uparrow$ Researcher contributing first author.
} 


\section{Introduction}

The general objective is to diagnose the motivation that our students in the last grades of the dental surgery major in the region of Veracruz-Boca del Rio have to continue with their graduate or specialty studies. That is to say, to find out the causes and factors that awaken this interest in students from public institutions such as the UV and private institutions such as the CME and the UVM. To do this, we suggest a correlative, comparative, and mixed study between both sectors of the university population, in order to see which population is more interested in entering a postgraduate program or specialty either in the area or outside. Education in Mexico is a controversial issue and from both the journalistic and academic point of view, it has been approached from different fields. On the one hand, major problems have been discussed, such as coverage, quality of education, adequate management, demanding access to basic education, basic education policies at the middle and higher levels, illiteracy, high dropout rates, modernization, and public education and teacher placement policies.

On the other hand, there has been criticism of the lack of sufficient resources to equip classrooms and teachers to achieve adequate efficiency in their functioning. Thus, although the issue of quality in education is an inexhaustible source, the issue of bilingual or intercultural education with its different protagonists and actors, so it is the accessibility to postgraduate studies by our young university students. To analyze this problem, we only have some case studies and some figures that show us this problem - where the importance of the subject is evident.

Currently, the different measures regarding education in our country seek to strengthen public, secular, and free education; to ensure greater equity in access to quality education; to strengthen school management capacities; to establish a professional teaching service with rules that respect the labor rights of teachers; to foster new opportunities for the professional development of teachers and principals; and to lay the groundwork for elements of the education system to be evaluated in an impartial, objective, and transparent manner.
All of this is aimed at achieving a substantial improvement in education; having a strengthened school; an evaluation that has as its axis the merit and recognition of the teaching vocation; an inclusive education that is within reach of all and, of course, the adequate management of resources destined to education. In this order, the panorama is complicated since young people and adolescents in our country tend to leave school prematurely. Sixty-two percent of 16-year-olds are enrolled in some institutions, while 35 percent of 18 -year-olds are in upper secondary education (19 percent) and higher education (16 percent). Of these, only $24 \%$ are enrolled.

Concerning graduate students, only 16 out of every 10,000 inhabitants study some specialty. For this reason, our efforts are oriented to investigate which are the reasons our young university students study or not a postgraduate or specialty. Bearing in mind that the efforts of our maximum house of studies are oriented to form highly qualified and competitive professionals in addition to the existence of different types of postgraduate and specialty programs in Pediatric Dentistry, Comprehensive Prosthodontics and Endodontics.

In the first chapter, "Approaches to the study of motivation," we address the ecological niche in which our subject is developed: education. For this reason, we will deal with the aspects related to the challenges, programs, and measures that have been taken in the field of basic and upper secondary education, to later clarify our objective: to investigate the specific aspects for which our university students in the faculty of dentistry opt or not to study a specialty or postgraduate course.

Likewise, we set out our objective after glimpsing the different schools or theoretical currents that have studied motivation. With this brief passage, we are in a position to develop our research approach, our general and specific objectives, and also to determine the importance of the subject. In the second chapter, "Theoretical and methodological framework," we review the different authors who have studied motivation, from classical authors to some more recent works to glimpse what criteria they have used to approach the study of human motivation. 
With this panorama, we discern our object of study: the determinants of motivation. It is supported by the angular concepts of our research: motivation, social structure, culture, and some other sociodemographic factors that we will call variables. Later, we continue with the development of our research, establishing its characteristics, that is, we expose what is its cohort and study sample at the same time that we describe the methods and techniques used for data collection.

In the third chapter (The Mexican Educational System), we describe the structure of the Mexican Educational System (SEM), its central norms, legislation, and educational policies since it is the niche where our subject of study, education, is based. In the same way, we review some graduate or specialty programs and scholarships offered by the same system. With this section, we intend to show some options available to our students and thus contribute to their interest in studying a program.

In the fourth chapter, we describe the area from which we obtain our universe and sample of study, the Faculty of Dentistry of the Universidad Veracruzana (U.V.), Campus Veracruz-Boca del Río. In this section, we make a brief semblance of the urban area, the Veracruzana University, and the Faculty of Dentistry. There, we review their study plan, the mission, vision, objectives of the faculty itself, etc., and their educational offerings.

In the following chapter, we show the conclusions we reached after the application of our collection instruments, such as questionnaires and previous interviews. With this, we intend to explain the reasons why our students are interested or not, in studying some postgraduate courses or specialty to finally conclude, with some suggestions to face this problem: the lack of motivation or disinterest in studying some postgraduate courses.

\section{Development of Sections and Sections of the Article with subsequent numbering}

The interest in studying the motivational factors that drive young university students to study a specialty or postgraduate studies has its origin in two main issues.
Firstly, from experience as a teacher in both public and private universities where I have had the opportunity to share dreams, experiences, aspirations, and concerns of my students regarding their short and medium-term life projects. Among them, it is worth mentioning the experience in the labor market as well as in some specialty or postgraduate courses.

Secondly, the little or no interest it has had at the research level in the same subject. In other words, the interest in finding out what are the determining factors in the choice of postgraduate studies, particularly the motivational factors of our university community to achieve greater specialization despite the existence of various programs focused on achieving this objective. In our opinion, the problem is severe, if we consider that only 16 out of 10 thousand Mexicans enter a graduate program according to estimates by the Scientific and Technological Advisory Forum (FCCyT) in 2014.

Of this figure, it remains to be seen how many students in our Veracruz community are accessing graduate studies. On the other hand, it is essential to point out that our work has more than an academic relevance (due to the thematic gap, since only a couple of articles and documentary sources address this problem) it has social relevance in the sense of worrying about the existence of a greater number of welltrained specialists as demanded by today's society in this information age.

With this work we humbly intend to contribute a grain of sand regarding "postgraduate and education" studies in our academic community. At the same time, we hope that this work will serve as a model to analyze the demands and aspirations of our university students after completing their university careers. Likewise, our work can be considered a model not only for the academic community but also for any survey, telemarketing, or advertising firm interested in knowing the aspirations and needs of our students. 
Finally and not less important, we want to emphasize that our work tries to reach two fundamental objectives: one, at a theoretical level, to propose the study of motivational and sociodemographic variables that surround the motivation-choice of our university students from any entity and academic community; whether public or private. Two, to propose within the academic body and teaching staff of our university community the development of programs, workshops, forums, consultations that help our young university students to enter a program of postgraduate studies or specialty.

The research was carried out in the urban area of Veracruz-Boca del Río. A questionnaire was applied regarding the motivation that students of the dental surgery major have to enter a postgraduate or specialty program. For this purpose, we methodologically and strategically selected three Higher Education Institutions (IES), one public school, and two private institutions. Within the first one, we have the Faculty of Dentistry of the Universidad Veracruzana (UV), Campus Boca del Río, and the Centro Mexicano de Estomatología (CME) and the Universidad del Valle de México (UVM); both belong to the private sector and the same Campus Veracruz. The specific objectives of the study were:

To prepare questionnaires that address the main socio-demographic factors of each of our university students: name, age, marital status, occupation, unit of residence, etc.;

To carry out interviews with a small group of students to find out first-hand what their opinion is of postgraduate studies within or outside the university;

To apply surveys and pilot questionnaires regarding the motivational factors that lead to the choice of such programs in other private or public faculties in the area;

To apply Likert scales to know the students' attitude towards the importance of postgraduate studies

To propose the realization of forums, workshops, consultations for a better knowledge of the educational offers after finishing their university major.
For our research, we will understand motivation as Palmero (2011), who states that any defining attempt at motivation must first include the adaptive process, i.e., the result of an internal state of an organism that is driven and directed towards action in a particular direction. That, in turn: includes the influence of both internal and external factors that activate the organism and direct it towards the achievement of some vital objective or goal". In this interactive process, the target objects are extremely relevant, along with their incentive characteristics, as well as the expectation or probability of achieving them.

The present study is of a correlational type to the extent that it responds to our fundamental needs during the research process. Its purpose is to evaluate the relationship between two or more concepts, categories, or variables in a particular context. The advantage of undertaking correlation studies is that it is possible to measure the degree of relationship between two or more variables. In other words, it is possible to quantify them and even propose some post hoc hypotheses after the research enterprise (Hernández, et al. 2003).

The study sample for our analysis will be of the non-probabilistic type since the survey applied will be of the social and exploratory type. In other words, one of the most widely used types of quantitative social research is a method of obtaining information through oral or written questions posed to a universe or sample of people who have the characteristics required by the research problem.

The population that integrates our sample is conformed by three groups of students of the Faculty of Dentistry of the UV, The Mexican Center of Stomatology, CME and the University of the Valley of Mexico, UVMthese last ones belonging to the private sector.

Each of these groups is made up of 12 and 15 students of both genders whose age ranges from 22 to 40 years old. Most of them are students in their final years and semesters, and in some cases, many of the students work or are parents as well as students.

The study was conducted through 4 axes described below. 
a)

The interview

An interview is a specific form of social interaction that aims to collect data for an inquiry. It is usually the researcher who asks questions of people he or she knows can suggest data or information of interest to him or her. By establishing a peculiar and asymmetric dialogue where one of the parties seeks to collect information, and the other is the source of that information, the environment of the interview is generated. For obvious reasons, it is only used, with rare exceptions, in the human sciences. The semi-structured interview works well for those who have little time to give an interview. This type of interview helps the interviewer in the sense of having preestablished themes or questions, resulting in the interviewee knowing that he/she is in front of a prepared, competent person with full control of the interview (Ibid. pp. 76 and 77).

\section{b) The survey}

Unlike a census where all members of the population are studied, surveys collect information from a portion of the population of interest, depending on the sample size for the study. We used a descriptive survey, the main objectives of which are: 1) to describe the distribution of one or more variables in the total or sample of the group under study; 2) to perform the same operation in significant subgroups of this group or its sample, and 3) to calculate measures of central tendency and the dispersion of these variables in the total or sample used and in the subgroups (Ibid. p. 52)

The fulfillment of the first objectives allows making various comparisons between the forms of distribution and the values taken by the variables in these contexts.

\section{c) Observation}

Observation consists of the systematic, valid, and reliable recording of manifest behavior or conduct. It can be used as a measuring instrument in a wide range of circumstances. By far, it is the most systematic and logical way to visually and verifiably record what one is trying to know; it is to capture in the most objective way possible, what happens in the real world, either to describe it, analyze it or explain it from a scientific perspective.
Observation is the elementary empirical procedure of science that has as its object of study one or several facts, objects, or phenomena of the current reality; therefore, in the case of natural sciences, any observed data will be considered as something factual, true or conclusive.

For us, this is the starting point to indicate that observation is a necessary procedure since it consists of using the senses and logic to have a more detailed analysis regarding the facts and realities that make up our object of study (Ditto). In other words, it regularly refers to the daily actions that yield data for the observer, and that, in turn, allows us to observe face-to-face aspects that would be difficult to obtain otherwise.

\section{d) Likert Scale}

Before starting with the description of this technique, it is convenient to indicate that we propose to measure the attitude that students of the dental surgery major have regarding the motivation to continue or not with their postgraduate studies and/or specialization. That is why we suggest the application of this technique. Bearing in mind that an attitude is a learned predisposition to respond favorably or unfavorably to an object, living being, activity, concept, person or symbols (Cit. by Gómez, 2011)

This indirect measurement will be done using scales in which, starting from a series of affirmations, propositions, or judgments, we will discover what attitudes students have regarding the motivation to continue preparing themselves. The scale is made up of a set of items presented in the form of statements or judgments, to which the participants are asked to react. In other words, each statement is presented, and the subject is asked to express his/her reaction by choosing one of the items or categories indicated (Sampieri, 2010)

Each point is assigned a numerical value so that the participant gets a score for the stated statement. What Likert did for the measurement of attitudes was something that was already common in the measurement of personality traits: the sum of a series of responses to supposedly homogeneous items. That is, they expressed the same trait and placed the subject in the measurement variable. 
In principle, Likert verifies unidimensionality, that is, that all the items are indicators of the same trait.

In summary, a Likert scale is constructed with a high number of statements that qualify the attitude object and are administered to a pilot group to obtain the group's scores on each item or statement where the scores are correlated with those of the group on the entire scale (the sum of the scores of all the statements). "The statements or reagents, whose scores correlate significantly with the scores of the full scale in order to select them for integration into the measurement instrument. The reliability and validity of the scale should also be calculated" (Sampieri, 2010, p. 252)

In this order, the survey applied for our research is an adaptation of the Motivations, Expectations, Values related to Learning questionnaire, MEVA 2005. A Spanish data collection tool concerning the assessment of motivational goals and orientations, expectations, and interests. It will be complemented with the measurement of attitude scales (Likert) around learning, orientation to specific goals such as school performance.

Taking into account that one of the precepts of motivation is to contemplate the process of motivation that begins with the presence of some internal or external stimulus or situation that triggers in the individual the need or desire to carry out a specific behavior. We consider it pertinent to evaluate the different activities that each student has undertaken to achieve this objective: whether or not to enter a postgraduate or specialty program.

This includes sociodemographic data of each respondent such as name, age, marital status, occupation, school institution, location etc; find out the reasons why they entered the major of dental surgeon, their life expectancy, and job growth. To know the reasons why they would enter a postgraduate or specialty program and the activities they have carried out to achieve this objective, such as obtaining good grades, paying attention in class, keeping their grades and homework up to date, having a self-taught preparation outside the classroom, such as studying a language other than Spanish, for example.
For this, the applied social survey includes four sections, on the one hand, those sociodemographic data that we pointed out previously. On the other hand, three batteries where each student will answer questions about life expectations, preparation, job growth after completing their degree studies; knowledge of the educational offer, i.e., postgraduate studies, scholarships, institutes or universities, forms of admission, etc. and finally, to know first-hand what activities they have been carrying out inside and outside the classroom to achieve this objective.

\section{Inclusion of Graphs, Figures and Tables - Editable}

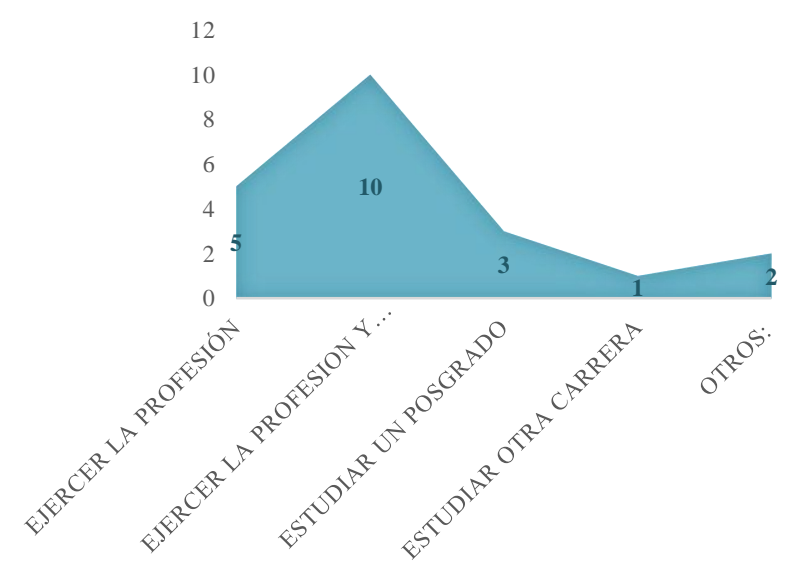

Graph 1 No. of U.V. F.O. students wishing to study a postgraduate degree

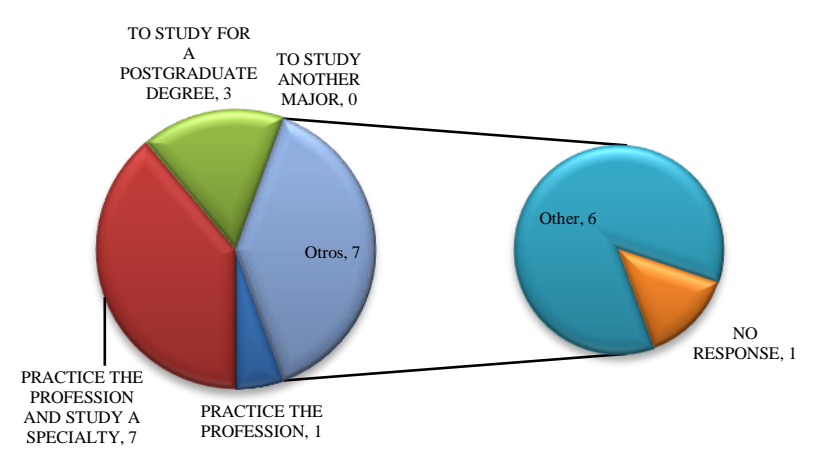

Graph 2 No. of students wishing to study a postgraduate degree
MORA-SÁNCHEZ, Aura Leonora, ROESCH-RAMOS, Laura, MORENO-MARIN, Flora and ZAPIÉN-USCANGA, Antonio de Jesús. Student motivation of the Surgeon Dentist Major of the Veracruz-Boca del Río Area to Study a Postgraduate Program: A Comparative Study. Journal of Social Researches. 2019 


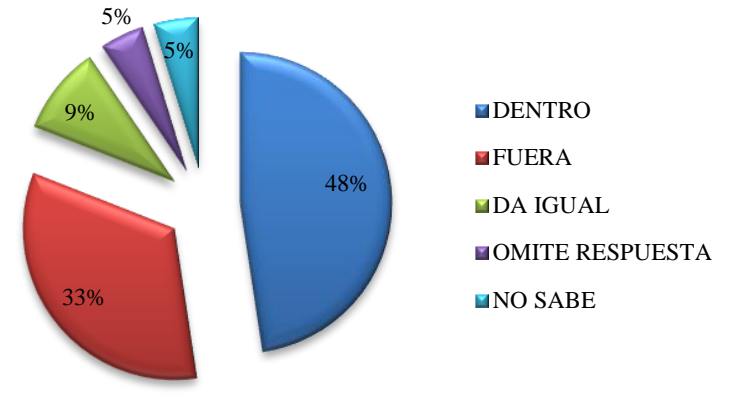

Graph 3 Students who wish to study a postgraduate course or speciality within and outside the ZCVB

They should not be images, everything should be editable

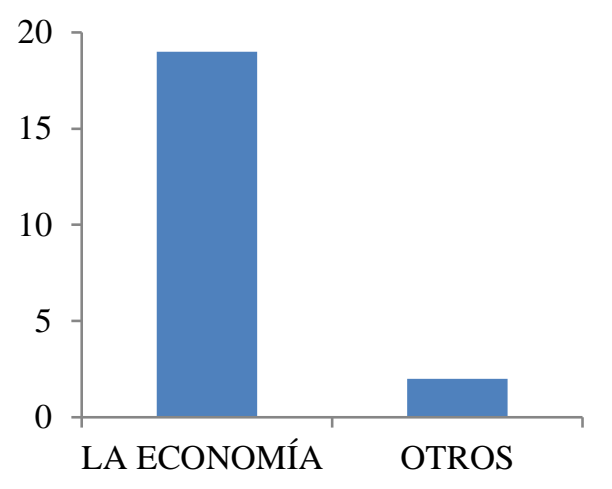

Graph 4 Main limitations when studying for a postgraduate degree or specialization

For the use of Equations, point out as follows:

\section{Without equations}

\section{Methodology to be developed}

By means of the 4 axes explained above.

\section{Results}

As a result, the following fact is worth underlining: the short and medium-term interest of university students in entering the labor market through the exercise of their profession and studying a specialty at the same time may explain the following findings: there is little interest in studying a postgraduate course, according to the analysis of our surveys. This explains the misinformation or lack of knowledge about the requirements or procedures that must be carried out to enter a graduate program or specialty $76 \%$ for the public sector and $56 \%$ for the private sector.
The majority of those surveyed stated that the university where they study had not provided them with the necessary information on the educational offer of postgraduate studies or specialties; $76 \%$ for the case of the U.V. and $56 \%$ for the case of private universities. Since studying a postgraduate degree is not as much of a priority as working, although they consider it indispensable. Thus, it is controversial that few students spend part of their time learning a foreign language - 19\% for both groups. That the performance of students in the classroom is declared to be high by very few percentage points (see Annex) and that they spend more time on activities such as work, family, and leisure.

\section{Annexes}

Annex 1 Survey of young university students of the zcvb

Motivation of dental surgery students from the conurbation veracruz-boca del rio to study a postgraduate degree

\section{Presentation}

The objective of the following questionnaire is to diagnose the motivation that students in the last grades of the dental surgery career in the Veracruz-Boca del Río conurbation have to enter a postgraduate or specialty program once they have completed their undergraduate studies. That is to say, to find out the causes and factors that awaken the interest of students from public institutions such as the Universidad Veracruzana (UV) and private institutions such as the Centro Mexicano de Estomatología (CME) and the Universidad del Valle de México, (UVM).

Sociodemographic data

Name:

Age: $\quad$ Gender:

Occupation:

Marital status:

Semester or grade:

Major

Name of the institution:

Address:

Location: 


\section{Block I}

\section{Expectations}

1.- Why did you enter the major of dental surgeon?

2.- What were your reasons for studying this major and not others?

3.- This degree completely fulfills your expectations of professional, personal or academic growth. Yes__ No___ Why? If you could start over, would you study another major, what would be your choice?

Do you plan to continue preparing yourself after you finish your studies? Yes__ No

6.- What are your life expectancies after completing your undergraduate studies?

7.- At what point in life do you think it is appropriate to study for a postgraduate degree?

8.- Making a parenthesis, are you interested in entering a course or postgraduate program or specialty after finishing your major as a dental surgeon? Yes No Why?

At this point in your life, would you study for a postgraduate degree? Yes___ No___ Why

10.- What do you consider to be the main limitations or obstacles to studying a postgraduate course or specialty?

\section{Block II}

\section{Educational offer}

11.- From the following list, which of these is familiar to you or you have heard most often (It may be more than one).

\section{a) IES b) ANUIES c) CONACYT d) COMEPO} f) $\mathrm{SEN}$

12.- From the above list, briefly indicate what the option indicated is in charge of.

13.- Mark with an " $\mathrm{X}$ " the reasons why you would study a postgraduate course or specialty.

To acquire more knowledge

For further specialization

To be more competitive

To get a better job

To have a well-paid job

Another one:

14.- Do you currently know of any graduate programs or specialties that are of interest to you? Yes__ No___ If yes, please list them.

15.- Has the university where you are studying provided you with the necessary information about the postgraduate or specialty education offerings at your campus?

Yes__ No

16.- Why would I study for a postgraduate degree or specialization?
17.- Do you know the requirements or procedures that must be carried out to enter a postgraduate or specialty study program?

Yes No

18.- Mark with an "X" what would be the main reason you would study for a postgraduate degree

The Family

Self-interest

Status

Self-improvement

Recognition of others

To better perform your profession

19.- Would you do your graduate study in a public or private school; why?

20.- Would the postgraduate or specialty study take place inside or outside the urban area - this includes other municipalities and other cities, of course. Why?

\section{Block III}

Motivation, learning and goal orientation 21.- How often do you do extracurricular activities outside the classroom?

a) Never b) Sometimes c) Regularly d) Always 22.- Do you think that academic preparation should only take place in the classroom?

Definitely yes

It probably is.

Undecided

Probably not.

Definitely not

23.- Do you think that academic preparation is indispensable for professional development?

a) Strongly agree b) Agree c) Neutral d) Disagree

(e) Strongly disagree

24.- In a percentage of 30 to 100, how committed are you to your school performance? $30 \%$ 40\% 50\% 60\% 70\% 80\% 90\% $100 \%$

25.- In addition to studying, what other activities do you do after school and on weekends?

Work

Family

Sport

Fun

Others

26.- When you set personal goals, do you really carry them out?

a) Never b) Sometimes c) Regularly d) Always 27.- How often do you set objectives or goals? a) Sometimes b) Regularly c) Always d) Never 28.- When you set an objective, you work hard until it is achieved or you abandon it; how often?

MORA-SÁNCHEZ, Aura Leonora, ROESCH-RAMOS, Laura, MORENO-MARIN, Flora and ZAPIÉN-USCANGA, Antonio de Jesús. Student motivation of the Surgeon Dentist Major of the Veracruz-Boca del Río Area to Study a Postgraduate Program: A Comparative Study. Journal of Social Researches. 2019 
a) Definitely yes b) Probably yes c) Undecided

d) Probably not

e) Definitely not

29.- As far as you are concerned, you prefer:

a) The challenges b) The easy jobs c) To please the teacher d) To be conformist e) To pass the subjects

30.- According to the following list, what do you expect from your professional training?

To pass the subjects

Getting good grades

Improve my skills and knowledge

\section{Block IV}

School performance activities

31.- From the following list, what activities you do outside your class schedule

Reading

Study

Learning a foreign language

Other: Please indicate which ones.

32.- During the class, I take notes on the most important points, while paying attention to what my teachers explain

a) Never b) Sometimes c) Regularly d) Always 33.- My classroom performance is higher than teachers require

a) Never b) Sometimes c) Regularly d) Always

I organize my time so that I schedule my homework and school activities to keep up with the topics seen in class

a) Never b) Sometimes c) Regularly d) Always 35.- Which of the following activities do you perform frequently?

Indispensable Very important Medium important Not very important

I do my own research,

I read encyclopedias, books, magazines, etc.

I go to the library

I surf on the internet

I go to my teachers to resolve my doubts

I attend research seminars or thesis consulting

36.- When I study difficult subjects I go over them again and again until I master them

a) Never b) Sometimes c) Regularly d) Always

37.- I attend classes regularly

a) Never b) Sometimes c) Regularly d) Always

38.- Regardless of my state of mind, my school performance is the same

a) Never b) Sometimes c) Regularly d) Always

39.- When I try to study I cannot concentrate or I am easily distracted

a) Never b) Sometimes c) Regularly d) Always
40.- I usually look for a pleasant environment to do my homework or study

a) Never b) Sometimes c) Regularly d) Always 41.- While I study or carry out my school activities I listen to music, the radio, watch television, surf the social networks (Facebook and/or Whats app)

a) Never b) Sometimes c) Regularly d) Always 42.- I participate actively in class, that is, I make comments, important questions, constructive criticism, etc.

a) Never b) Sometimes c) Regularly d) Always

\section{Acknowledgments}

Not funded. We are grateful for the support of private universities in the Boca del Río Conurbation, Veracruz.

\section{Conclusions}

In summary, this leads us to reflect that the "desire" to call the motivation to study a postgraduate degree is not always accompanied by actions, behaviors, and commitments aimed at achieving this goal. Instead, they are aimed at more practical issues such as finishing their studies, practicing their profession, entering the labor market, and studying a specialty at the same time.

\section{References}

Artiles M. F., Martín, O. Kappel J., Poliak., J., Rebagliati P., Sánchez A., (1995) Psicología, Humanista, Buenos Aires: Editorial Docencia.

ANUIES. (2014). Programa de trabajo 2014, MEXICO: SECRETARÍA GENERAL EJECUTIVA, SEP, available at http://consejo12014.portal.anuies.mx/wpcontent/blogs.dir/8/files/sites/8/2014/03/11_Pro grama_de_Trabajo_2014.pdf

[en línea] Anuario Estadístico de Educación Superior, ciclo 2014-2015 México, ANUIES, 2015, available at http://www.anuies.mx/iinformacion-yservicios/informacion-estadistica-de-educacionsuperior/anuario-estadistico-de-educacionsuperior

Arnau Gras, Jaime. (1985). El estudio de la motivación humana. Barcelona: Universidad de Barcelona. 
Artiles M., Martin M., Kappel J., Poliak J., Rebagliati P y Sánchez A., (1995) Psicología Humanista. Aportes y orientaciones Argentina: Docencia

Ávila, Héctor Luis (2006). Introducción a la metodología de la investigación. Mexico: Eumed, Universidad de Guadalajara

Aboites, Hugo, (Año 2012). El derecho a la Educación en México, Del liberalismo decimonónico al Neoliberalismo del siglo XXI, .Revista Mexicana de Investigación Educativa, 17, 361-389, available at http://revele.com.veywww.redalyc.org/articulo. oa? id=14023105003

Arredondo Galván Víctor M, (2003) La situación actual del posgrado en México. Hacia un Plan de Posgrado Nacional, Revista de la Coordinación de Estudios de Posgrado 19, 101108 ,

Ávila Rosalinda, (Abril de 2005) "Mujeres, trabajo y familias" en Suplemento Letras, Sexualidad y Sida, La Jornada, available at http://studylib.es/doc/141831/radiografiafamilias---equidad-de-g\%C3\%A9nero-ciudadan\%C3\%ADa--tra...

AVELI, (2010) Catálogo de las lenguas indígenas y sus variantes lingüísticas del Estado de Veracruz, México: Gobierno del Estado de Veracruz, Academia Veracruzana de las Lenguas.

Balaguer Isabel, Castillo Isabel y Tomás Inés (1997) Las Orientaciones de Metas de logro como Predictoras de las conductas de salud en los Adolescentes, Facultad de Psicología, 2, 210 ,

http://www.uv.es/icastill/documentos/1997.Bal aguerCastilloTomasDuda97_Iberpsicologia.pdf

Barrón Tirado, Concepción y Gloria A. Valenzuela (Coord.). (2013). El posgrado programas y prácticas, Mexico: UNAM, IISUE.

Behar Rivero, Daniel S, (2008) Metodología de la investigación, Mexico: Shalom.
Benguría B., Alarcón S. M, Valdés Ma. V., Pascale P., Gómez L. (2015) Métodos de Investigación en educación especial en https://www.uam.es/personal_pdi/stmaria/jmuri 1lo/InvestigacionEE/Presentaciones/Curso_10/ Observacion_trabajo.pdf

Bernal, César A. (2010) Metodología de la investigación: Administración, Economía, Humanidades y Ciencias Sociales, Colombia: Pearson, Universidad de La Sabana

Bernal Guerrero, Antonio y Antonio R. Cárdenas (2005) Procesos motivacionales y Educación Universitaria. Un estudio sobre la motivación inicial de los estudiantes de Pedagogía, Revista Cuestiones Pedagógicas, 17, 199-216, available at http://institucional.us.es/revistas/cuestiones/17/ art_12.pdf

Boca del Río, (2014) Plan de Desarrollo Municipal 2014-2017, available at http://bocadelrio.gob.mx/wpcontent/uploads/2015/10/PLAN-DE-

DESARROLLO-2014.pdf

Briones, Guillermo, (1996) Metodología de la investigación cuantitativa en las Ciencias Sociales, Programa de especialización en Teoría, Métodos y Técnicas de Investigación Social, Colombia: ICFES

Brown, A. Reginald (1972) Estructura y función en la sociedad primitiva, Spain: Península,

Campos, Guillermo y Covarrubias (2012) La observación, un método para el estudio de la realidad, Revista Xihmai, 7 (13), 45-60,

Cantón, Enrique Luis Mayor y Pallarés J, "Factores Motivacionales y afectivos en la iniciación deportiva" Revista de Psicología General y Aplicada, 1995, 48 (1) 59-75.

Castelló Cogollos, Rafael "Estructura social del País Valenciano", Valencia, Universidad de Valencia, 2002, Document available at http://www.uv.es/ socant2/Portada.pdf

CONABIO (2013) Estrategia para la Conservación y uso sustentable de la biodiversidad del estado de Veracruz, México: Conabio, Gobierno del Estado de Veracruz, Sedema, Pladeira S.C.,Sendas A.C. 
CONEVAL, [en línea] Consejo Nacional de Evaluación de la pobreza, Pobreza por municipio 2010, available at http://www.coneval.gob.mx/Medicion/MP/Pagi nas/Medicion-de-la-pobreza-municipal2010.aspx

Cortés Manuel, Iglesias M, (2004) Generalidades sobre metodología de la investigación, Mexico: Universidad Autónoma del Carmen, Colección Material Didáctico.

Cholis, Mariano (2004) Psicología de la Motivación: el proceso motivacional, Universidad de Valencia, available at http://www.uv.es/ choliz.

Cuche, Denys (2002) La noción de la cultura en las ciencias sociales, Argentina, Buenos Aires: Nueva Visión

Cuevas Molina, Rafael "El concepto de cultura" available http://www.repositorio.una.ac.cr/bitstream/hand le/11056/2526/recurso_629.pdf?sequence=1,

Delgado María y Di Antonio A, (2010) La motivación laboral y su incidencia en el desempeño organizacional: un estudio de caso, (Tesis de licenciatura inédita), Universidad Central de Venezuela, Caracas.

Flores Salgado, José [Coord.] (2010) Pensar el futuro de México. Crecimiento y desarrollo económico de México, Mexico: UAM

Firth, Raymond (1976) Elementos de Antropología social, Buenos Aires: Amorrortu,

Gallegos Jiménez, Oswaldo, (2008) Organización espacial del corredor turístico Veracruz-Boca del Río, Teoría y Praxis, 5, 171186. García Ferrando, Manuel, Ibáñez J., y Alvira F., [Comp.] (1996) El análisis de la realidad social Métodos y técnicas de investigación, Spain: Alianza,

Gómez-Peresmitré, Gilda y Reidl L.( s/f), Metodología de investigación en Ciencias Sociales Manuscrito, Mexico: UNAM,

González Diego Jorge, (2008) Psicología de la motivación, La Habana, Cuba: EcmedEditorial Ciencias médicas.
Gobierno del Estado de Veracruz, (2007) Análisis del crecimiento urbano e impacto en el ambiente biofísico del área conurbada de la ciudad de Veracruz: El caso del municipio de Boca del Río, Mexico: UNAM, Semarnat, Inecol.

Programa rector del desarrollo litoral del estado de Veracruz, de Ignacio de la Llave, Mexico: Gobierno del estado de Veracruz, SCT, 2010

(2011) Estudios regionales para la Planeación, Región Sotavento, Mexico: Gobierno del Estado de Veracruz

(2012) Plan

Veracruzano de Desarrollo 2011-2016, Mexico: Gobierno del Estado.

(2012) Estudios regionales para la planeación, Información básica, Mexico: Gobierno del Estado de Veracruz, Sefiplan, Copladever.

(2012) Sistema

Educativo de los Estados Unidos Mexicanos, Principales cifras ciclo escolar 2011-2012, Mexico: Dirección General de Planeación y Programación.

(2014) VeracruzBoca del Río, Agendas de Competitividad de los destinos turísticos de México, Mexico: Gobierno del Estado, Sectur, Fonatur, El Colegio de Veracruz

(2014) VeracruzBoca del Río, Agendas de Competitividad de los destinos turísticos de México, Gobierno del Estado, Sectur, Fonatur, El Colegio de Veracruz, 2014

(2015) Cuadernillos municipales 2015, Mexico: Gobierno del Estado, Sefiplan,

Hernández, J. Villegas, S., Padilla I. Gutiérrez A. y González J.A. (2008) Juárez: Visiones desde el presente, Mexico: FLM, UNAM

Hernández González, Marisela, (2002) Motivación animal y humana, Mexico: Universidad de Guadalajara. 
Hernández S., Fernández, R., y Bap P., (2003)

Metodología de la Investigación, Mexico: MacGrawill

Hernández Sampieri, et. al, (2006) Metodología de la Investigación Mexico: MacGrawill.

Hernández Sampieri Roberto (2010)

Metodología de la investigación, Mexico:

McGrawHill

Huertas, Juan Antonio (1997) Motivación querer aprender, Argentina: Aique

INEE, (2009) El derecho a la Educación en México, Mexico: INEE

(2009) Estructura y Dimensión del Sistema Educativo Nacional, Mexico: INEE.

, (2010) El derecho a la Educación en México, Mexico: INEE.

, (2014) El derecho a una educación de calidad, México. Informe 2014, Mexico, INEE, 2014 available at http://publicaciones.inee.edu.mx/buscadorPub/ P1/D/239/P1D239.pdf, consultado

INEE, (2014) Panorama Educativo de México, Indicadores del Sistema Educativo Nacional Educación básica y media superior, Mexico: INEE

, (2015) Panorama Educativo de México, Indicadores del Sistema Educativo Nacional 2014. Educación básica y media superior, Mexico: INEE

INEGI, (2015). Inegi e Inmujeres presentan los resultados de la encuesta

Nacional sobre uso del tiempo 2014 de Inmujeres web: http://www.inegi.org.mx/saladeprensa/boletines /2015/especiales/especiales2015_07_2.pdf

MORA-SÁNCHEZ, Aura Leonora, ROESCH-RAMOS, Laura, MORENO-MARIN, Flora and ZAPIÉN-USCANGA, Antonio de Jesús. Student motivation of the Surgeon Dentist Major of the Veracruz-Boca del Río Area to Study a Postgraduate Program: A Comparative Study. Journal of Social Researches. 2019 